\title{
MOVEMENT OF POTASSIUM INTO SKELETAL MUSCLE DURING SPONTANEOUS ATTACK IN FAMILY PERIODIC PARALYSIS ${ }^{1}$
}

\author{
BY KENNETH L. ZIERLER AND REUBIN ANDRES \\ (From the Departments of Environmental Medicine and Medicine, The Johns Hopkins \\ University and Hospital, Baltimore, Md.)
}

(Submitted for publication July 5, 1956; accepted January 24, 1957)

It has been appreciated since the classical studies of Biemond and Daniels (1) and Aitken, Allott, Castleden, and Walker (2) that the concentration of potassium in serum falls during attacks in patients with typical family periodic paralysis. Allott and McArdle (3), Pudenz, McIntosh, and McEachern (4) and Ferrebee, Atchley, and Loeb (5) showed that the quantity of potassium excreted in urine was reduced during attacks of paralysis. These observations implied that during attacks potassium shifted from extracellular to some intracellular space. Metabolic balance studies by Danowski, Elkinton, Burrows, and Winkler (6) confirmed this hypothesis. The question of which intracellular space accepted the potassium that shifted during attacks remained unanswered.

Recently it has been reported from this laboratory that there is a diurnal variation in normal man in exchange of potassium between skeletal muscle and extracellular water (7). During the hours between 10 P.M. and 12 noon, that is, 4 to 18 hours after the last meal, with the subject at rest, potassium moves from muscle to blood, the rate declining to a minimum or even reversing slightly (potassium moves from blood to muscle) between the hours of midnight and 7 A. M., and then rising again to a peak between 10 A.M. and noon. It is characteristic of family periodic paralysis that most attacks begin during the middle of the night (8). This suggested that in patients with this disease there may be an exaggeration of the diurnal variation in potassium movement, and that movement of potassium from extracellular fluid into skeletal muscle during the night might be re-

1 This work was performed under a contract between the Office of Naval Research, Department of the Navy, and The Johns Hopkins University (NR 113-241) and was further supported by grants-in-aid from the National Institutes of Health, Department of Health, Education, and Welfare (A-750) and the Muscular Dystrophy Associations of America, Inc. sponsible for the attacks. It is the purpose of this report to present data indicating that this is the case.

\section{METHODS}

Two subjects were studied. Both had well-documented family periodic paralysis with a history of spontaneous attacks of flaccid paralysis frequently having their onset in the middle of the night and associated with definite hypokalemia.

Subject $M$. H., a 14-year-old boy weighing $57 \mathrm{Kg}$., had had episodes of weakness and paralysis since age 12 . All the attacks began between 11 P.M. and 9 A.M. They were relieved or prevented by administration of potassium chloride, and serum potassium concentration during at least one attack was found to be low. The severity of his attacks was much less than that of the second patient.

Subject M. H. was studied on three occasions :

Study I was performed between 11:30 A.M. and 12 noon during spontaneous recovery from a mild attack which had begun spontaneously during the night. $\mathrm{He}$ had had no food since supper at 6 P.M. the evening prior to study.

Study II covered the hours between midnight and 7 A.M. The last meal was at 6 P.M. When a spontaneous attack did not occur by 2:20 A.M., an attack was induced by administration of glucose and of insulin.

Study III covered the hours between 1 A.M. and 7 A.M. During the afternoon prior to study M. H. exercised heavily on a treadmill and at 6 P.M. ate a large dinner. There was no clinical evidence of an attack during the time of this study.

Subject $A$. $B$., a 24-year-old college student weighing $77 \mathrm{Kg}$., was a member of a family of whom six members had clinical evidence of periodic paralysis. His attacks began at age 12 . There were one to three severe attacks and more frequent mild attacks each month until age 18 when he was first placed on prophylactic potassium therapy. Circumstances under which attacks occurred were quite predictable. Attacks followed heavy exercise and high carbohydrate meals, were aborted by mild exercise and ingestion of potassium chloride. Onset of attacks was usually in the middle of the night and some of his attacks were quite severe, involving not only the extremities but also respiratory muscles.

Subject A. B. was studied on one occasion. Prophylactic potassium therapy was discontinued 24 hours prior 
TABLE I

Net movement of potassium during spontaneous nocturnal attack-Subject $A . B .^{*}$

\begin{tabular}{|c|c|c|c|c|c|c|}
\hline $\begin{array}{l}\text { Time } \\
\text { A.M. }\end{array}$ & $\underset{m E_{Q} . / L}{\mathrm{~A}}$ & $\underset{m E q . / L .}{A-V^{-}}$ & $\begin{array}{l}Q \\
100 \mathrm{mi} . / \mathrm{min} . / \\
\text { morearm }\end{array}$ & $\underset{\mathbf{~ O r a l ~}}{\mathrm{KCl}}$ & Muscle strength & Tendon reflexest \\
\hline $12: 12$ & 2.47 & 0.74 & 1.8 & & Normal & $\begin{array}{l}\mathrm{B}-1 ; \mathrm{T}-2 \\
\mathrm{~K}-2,2\end{array}$ \\
\hline $\begin{array}{c}1: 08 \\
1: 25 \\
\text { to }\end{array}$ & 2.11 & 0.60 & 1.3 & & $\begin{array}{l}\text { Rapid decrease in arms; legs } \\
\text { fairly strong. }\end{array}$ & $\begin{array}{l}\mathrm{B}-0 ; \mathrm{T}-0 \\
\mathrm{~K}-1,0 ; \mathrm{A}-2,1\end{array}$ \\
\hline $\begin{array}{l}2: 08 \\
2: 55\end{array}$ & 2.11 & 0.55 & 0.9 & & $\begin{array}{l}\text { Maximal inspiration reduced, } \\
\text { but no dyspnea. Neck } \\
\text { flexion very weak. }\end{array}$ & \\
\hline $\begin{array}{l}3: 08 \\
4: 00\end{array}$ & $\begin{array}{l}1.91 \\
1.85\end{array}$ & $\begin{array}{l}0.44 \\
0.49\end{array}$ & $\begin{array}{l}0.8 \\
1.1\end{array}$ & & $\begin{array}{l}\text { Extremities almost totally } \\
\text { paralyzed. (Severe EKG } \\
\text { abnormalities.) }\end{array}$ & \\
\hline $\begin{array}{l}4: 10 \\
4: 40\end{array}$ & & & & $\begin{array}{l}5 \\
5\end{array}$ & $\begin{array}{l}\text { Subjective improvement. No } \\
\text { objective change. }\end{array}$ & $\begin{array}{l}\text { B-0; T-1 } \\
\text { K-0;0;A-2, } 1\end{array}$ \\
\hline $\begin{array}{l}5: 48 \\
6: 25\end{array}$ & $\begin{array}{l}2.75 \\
2.73\end{array}$ & $\begin{array}{l}0.61 \\
0.36\end{array}$ & $\begin{array}{l}0.8 \\
0.7\end{array}$ & 5 & $\begin{array}{l}\text { EKG less abnormal } \\
\text { Extremity strength slightly } \\
\text { improved. Inspiration } \\
\text { stronger. (EKG-return } \\
\text { to severe changes.) }\end{array}$ & $\begin{array}{l}\mathrm{B}-0 ; \mathrm{T}-2 \\
\mathrm{~K}-1,0 ; \mathrm{A}-2,1\end{array}$ \\
\hline $\begin{array}{l}7: 10 \\
7: 13 \\
7: 43\end{array}$ & $\begin{array}{l}3.11 \\
3.45\end{array}$ & $\begin{array}{l}-0.20 \\
-0.50\end{array}$ & $\begin{array}{l}-0.4 \\
-0.8\end{array}$ & 5 & Head can be raised off pillow. & \\
\hline 9:00 & 5.40 & -0.61 & -1.3 & & Nearly recovered. & $\begin{array}{l}\mathrm{B}-2 ; \mathrm{T}-1 \\
\mathrm{~K}-3,2 ; \mathrm{A}-2,2\end{array}$ \\
\hline $10: 03$ & 5.91 & -0.33 & -0.7 & & Essentially normal. & \\
\hline
\end{tabular}

* $\mathrm{A}=$ concentration of potassium in arterial plasma; $\mathrm{A}-\mathrm{V}=$ arteriovenous difference in plasma concentration of potassium; $Q=$ net uptake (or net release when value is negative) of potassium by forearm tissues.

† $\mathrm{B}=$ biceps, $\mathrm{T}=$ triceps, $\mathrm{K}=$ knee, $\mathrm{A}=$ ankle. Only the right biceps and triceps reflexes could be tested; metabolic studies were made on the left arm. $0=$ absent, $1=$ reduced, $2=$ normal, $3=$ hyperactive. In the knee and ankle jerks, the first number refers to the right side, the second to the left side.

to this study. He received $100 \mathrm{~g}$. of glucose at 3:30 P.M., ate his usual supper at $5: 30$ P.M. with extra dessert plus $100 \mathrm{~g}$. of glucose at 6:30 P.M. Measurements were made between midnight and 10 A.M. A severe attack occurred and it was necessary to treat him with $\mathrm{KCl}$.

Measurements were made of the metabolism of forearm muscles with the subject at rest. Uptake and release of potassium, $\mathrm{O}_{2}, \mathrm{CO}_{2}$, glucose and lactate were calculated as described previously $(7,9)$ as the products of forearm blood flow and arteriovenous differences of the metabolites. Venous blood was obtained through a catheter placed in a deep vein draining forearm muscles. Arterial blood was from the brachial artery. A pressure cuff about the wrist, inflated to greater than systolic pressure, excluded blood flow to hand and wrist during periods of blood collection.

Certain extrapolations of the data are made. In these it is assumed that uptake or output per min. per $100 \mathrm{ml}$. of forearm can be converted to uptake or output per min. per $100 \mathrm{~g}$. of forearm muscle by multiplying by $f_{3}$, a conversion factor estimated previously (9). It is further assumed that extracellular fluid weighs 20 per cent of body weight and that total muscle mass is $\mathbf{4 0}$ per cent of body weight.

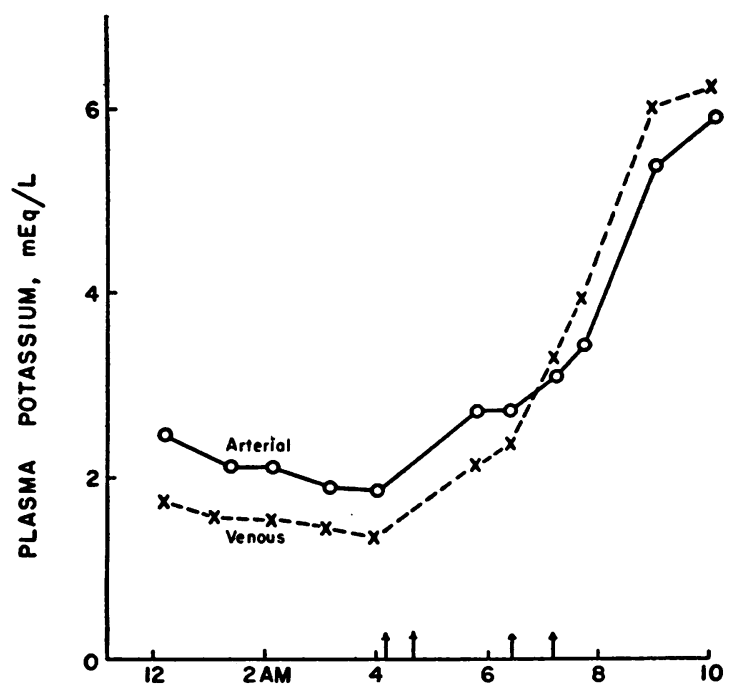

Fig. 1. Arterial and Venous Plasma Potassium Concentrations During Attack and Recovery in Patient A. B.

At each time indicated by arrows $5 \mathrm{~g} . \mathrm{KCl}$ was given orally. 
RESULTS AND DISCUSSION

\section{Potassium Movement During Spontaneous Attack and Spontaneous Recovery}

Subject A. B. (Table I and Figures 1 and 2)

Arterial potassium concentration was already reduced greatly by the time the first sample was drawn at midnight and continued to fall for the next four hours, after which it was necessary to treat the patient by administration of $\mathrm{KCl}$. In subject A. B., between midnight and 4 A.M., extraction of potassium (i.e., $\mathrm{A}-\mathrm{V}$ difference divided by arterial concentration) was approximately 25 per cent. In normal subjects little or no extraction of potassium occurs during these hours.

During the attack potassium moved from plasma into muscle at a rate of $1.2 \mu \mathrm{Eq}$. per min. per 100 $\mathrm{ml}$. forearm. Between midnight and 4 A.M., concentration of potassium in arterial plasma fell 0.6 $\mathrm{mEq}$. per L., a loss of about $9.5 \mathrm{mEq}$. of potassium from total extracellular fluid. During that time about $2 \mathrm{mEq}$. of potassium moved from plasma into muscles of one forearm. If all skeletal muscles were behaving identically, about 110 $\mathrm{mEq}$. of potassium might have moved from extracellular fluid into muscle in the four-hour period. Since this figure is about 12 times as large as the estimated loss of extracellular potassium it follows either that forearm muscles were extracting potassium from plasma at a rate about 12

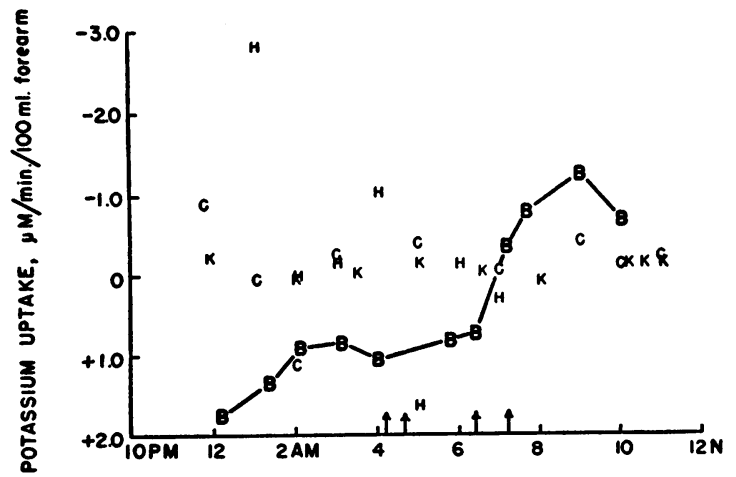

Fig. 2. Potassium Movement Between Plasma and Muscle During the Night

Positive values are uptake, negative values are release from muscle. B, subject A. B. during attack and recovery; $K$ and $C$, normal subjects; $H$, subject $M$. $H$. who had periodic paralysis but failed to get an attack during this study. Arrows indicate oral administration of 5 g. $\mathrm{KCl}$ to $\mathrm{A}$. $\mathrm{B}$. times greater than the average muscle or that potassium was added to plasma from some nonmuscular source.

Although the mass of potassium lost from extracellular fluid was large from the viewpoint of extracellular potassium, if it all went into skeletal muscle this quantity of potassium would be sufficient to raise the average concentration of intramuscular potassium by only a few per cent, an amount too small to be detected by available methods.

When $\mathrm{KCl}$ was administered, although there was some elevation of arterial potassium concentration, extraction of potassium remained constant for the next two and one-half hours and potassium continued to move into muscle until the direction of movement was reversed at 7 A.M., several hours earlier than the onset of accelerated output of potassium by muscle in normal subjects.

In summary, an attack of paralysis developed in the middle of the night about seven hours after a heavy carbohydrate meal. Potassium moved from plasma into skeletal muscle, concentration of potassium in plasma was reduced and paralysis occurred. Efforts to terminate the attack by oral administration of potassium failed to do so during a two-hour period in which potassium continued to move from plasma into muscle and there was only a small increase in concentration of arterial potassium. Presumably, during these two hours potassium movement out of extracellular space into muscle almost kept pace with intestinal absorption of administered potassium. Later in the morning the direction of potassium movement reversed; potassium moved out of muscle into extracellular space at a rate greater than that seen in normal subjects during these hours. Concentration of potassium in arterial plasma rose abruptly and the attack ended. Although the rise in concentration of potassium in arterial plasma may have been the result of absorption of administered potassium from the gut as well as of outpouring of potassium from skeletal muscle, the latter factor alone was sufficient to account for the observed rise in plasma concentration.

\section{Subject M. H., Study I (Table II, Figure 3)}

Subject M. H. failed to have a spontaneous attack during the time measurements of forearm 
TABLE II

Potassium release during spontaneous recovery from spontaneous attack-Subject $M . H_{\text {.* }}^{*}$

\begin{tabular}{cccc}
\hline Time & A & A-V & ¿ \\
\hline $11: 39$ & 4.09 & -1.05 & -3.85 \\
$11: 50$ & 4.10 & -1.15 & -6.23 \\
$12: 00$ & 4.08 & -0.87 & -3.70 \\
\hline
\end{tabular}

* Time is A.M. Symbols as in Table I.

metabolism were made. However, forearm metabolism was measured on the morning following a mild spontaneous attack from which he was recovering spontaneously. At the time of the study there was no longer any gross weakness. Deep tendon reflexes in the arms were normal but patellar and ankle responses were still slightly depressed. Release of potassium from muscle was about six times greater than the average rate found in normal subjects during the same time of the day. Presumably at some earlier hour during the attack there was a reduction in plasma potassium concentration. The rate at which potassium moved from muscle to extracellular fluid during recovery, 3 to $5 \mathrm{mEq}$. per $\mathrm{hr}$. per $\mathrm{Kg}$. of muscle, was adequate to account for an increase in plasma potassium concentration. Despite the large contribution of potassium to venous plasma from muscle, concentration of potassium in arterial plasma was stable at about $4 \mathrm{mEq}$. per L. during the period of observation. This stability of arterial potassium could obtain only if potassium left the blood stream by some other route as fast as it entered from skeletal muscle.

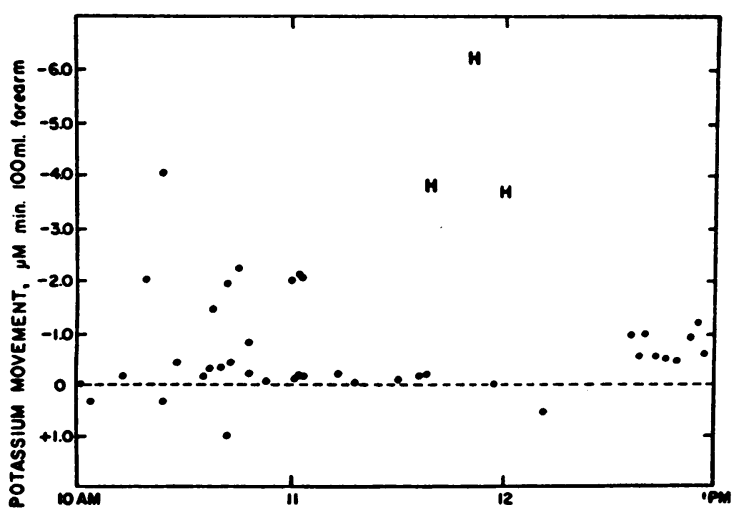

Fig. 3. Potassium Output from Muscle to Plasma During Spontaneous Recovery from a Spontaneous Attack of Paralysis in Subject M. $H$.

- data from normal subjects in the basal state.
Potassium Movement During an Attack Produced by Administration of Glucose and Insulin

Subject M. H., Study II (Table III)

During Study II of subject M. H., when a spontaneous attack had not occurred by $2: 20$ A.M. a mild attack was produced by administration of glucose and insulin. At 6:25 A.M. he was given $9 \mathrm{~g} . \mathrm{KCl}$ by mouth. Within 25 minutes there was some return of deep tendon reflexes.

When $\mathrm{KCl}$ was administered there was a rapid rise in arterial potassium concentration despite a large increase in rate of potassium uptake by muscle. An uptake of this magnitude did not occur following potassium administration to subject A. B. at approximately the same time of day. The difference in response is probably attributable to the effect of insulin, since the behavior of blood glucose concentrations indicated that a potent insulin action occurred at the time of massive uptake of potassium.

From the rise in concentration of potassium in

TABLE III

Net movement of potassium during attack induced by glucose and insulin-Subject M. H., Study II*

\begin{tabular}{|c|c|c|c|c|}
\hline $\begin{array}{l}\text { Time } \\
\text { A.M. }\end{array}$ & $\underset{m E q . / L}{\mathrm{~A}}$ & $\underset{m E q . / L}{\mathrm{~A}-\mathrm{V}}$ & $\underset{\substack{\mu \mathrm{Q} \\
\text { min./100 } \\
\text { ml. forearm }}}{\dot{\text { for }}}$ & Comments \\
\hline $12: 20$ & 4.41 & -0.06 & -0.4 & $\begin{array}{l}\text { Strength and reflexes } \\
\text { normal. }\end{array}$ \\
\hline $\begin{array}{l}1: 20 \\
2: 21\end{array}$ & $\begin{array}{l}4.44 \\
4.31\end{array}$ & $\begin{array}{l}-0.11 \\
-0.16\end{array}$ & $\begin{array}{l}-0.8 \\
-1.2\end{array}$ & No symptoms or signs of \\
\hline $\begin{array}{l}2: 25 \\
\text { to } \\
2: 40\end{array}$ & & & & $\begin{array}{l}130 \mathrm{~g} . \text { glucose in } 240 \mathrm{ml} \text {. } \\
\text { orange juice. }\end{array}$ \\
\hline $2: 40$ & & & & $\begin{array}{l}\text { Insulin, } 20 \text { U., subcu- } \\
\text { taneous. }\end{array}$ \\
\hline $\begin{array}{l}3: 02 \\
3: 55\end{array}$ & $\begin{array}{l}4.09 \\
4.18\end{array}$ & $\begin{array}{l}-0.34 \\
-0.01\end{array}$ & $\begin{array}{l}-2.6 \\
-0.1\end{array}$ & $\begin{array}{l}\text { No change in strength or } \\
\text { reflexes. }\end{array}$ \\
\hline $\begin{array}{l}3: 55 \\
\text { to } \\
4: 05\end{array}$ & & & & $25 \mathrm{~g}$. glucose, I.V. \\
\hline $\begin{array}{l}4: 07 \\
4: 41\end{array}$ & 3.68 & 0.08 & 0.7 & $\begin{array}{l}\text { Insulin, } 6 \text { U., I.V. } \\
\text { Strength greatly } \\
\text { diminished. Tendon } \\
\text { reflexes absent. }\end{array}$ \\
\hline $\begin{array}{l}5: 29 \\
6: 03 \\
6: 15\end{array}$ & $\begin{array}{l}3.73 \\
3.68\end{array}$ & $\begin{array}{l}0.26 \\
0.03\end{array}$ & $\begin{array}{l}1.8 \\
0.3\end{array}$ & \\
\hline $\begin{array}{l}6: 25 \\
6: 40\end{array}$ & 4.95 & 0.68 & 6.6 & $\begin{array}{l}\text { Further weakness. Re- } \\
\text { flexes remain absent. } \\
9 \mathrm{~g} . \mathrm{KCl} \text { orally. } \\
\text { Reflexes and strength re- } \\
\text { turning. }\end{array}$ \\
\hline $6: 58$ & 5.56 & 0.45 & 6.7 & $\begin{array}{l}\text { Almost complete } \\
\text { recovery. }\end{array}$ \\
\hline
\end{tabular}

* Symbols as in Table I. 
arterial plasma, from the measured uptake of potassium by muscles of the forearm, and from reasonable assumptions of the size of extracellular space and total muscle mass in $M$. $H$. it can be estimated that of the $120 \mathrm{mEq}$. of potassium administered about $20 \mathrm{mEq}$. went into extracellular space and about $65 \mathrm{mEq}$. went into skeletal muscle in 33 minutes, leaving about one-fourth unaccounted for. Similar calculations made for the case of A.B. following the first $10 \mathrm{~g}$. of administered $\mathrm{KCl}$ (Table I) indicated that of the $135 \mathrm{mEq}$. of potassium administered about 14 $\mathrm{mEq}$. went into extracellular space and about 35 $\mathrm{mEq}$. went into muscle in two hours, leaving about two-thirds of the potassium unaccounted for. This suggests that the failure of oral administration of $\mathrm{KCl}$ to produce prompt restoration of normal potassium concentration in arterial plasma and clinical recovery may have been in part due to delayed absorption of potassium from the gut during the more severe attack suffered by A. B.

\section{Normal Pattern of Potassium Movement During a Night When No Paralytic Attack Occurred}

\section{Subject M. H., Study III (Figure 2)}

During the early part of Study II, between midnight and 2:20 A.M., subject M. H. had no spontaneous attack and potassium movement at this time was indistinguishable from that observed in normal men. In Study III, between 1 A.M. and 7 A.M., subject M. H. again had no spontaneous attack and potassium movement appeared to be normal.

\section{Fragmentary Observations on Other Abnormali- ties of Muscle Metabolism Occurring During a Spontaneous Attack of Paralysis (Table IV)}

Certain observations discovered during the attack in A. B. which differ from those obtained in normal subjects are reported. These differences may prove ultimately to be of no significance since the number of normal subjects studied is small. On the other hand, even if they prove to be real departures from the normal it is not clear whether these differences are fundamental to the disease, whether they represent a defect parallel to but unrelated to the anomaly of potassium movement, whether they are in some way causally related to

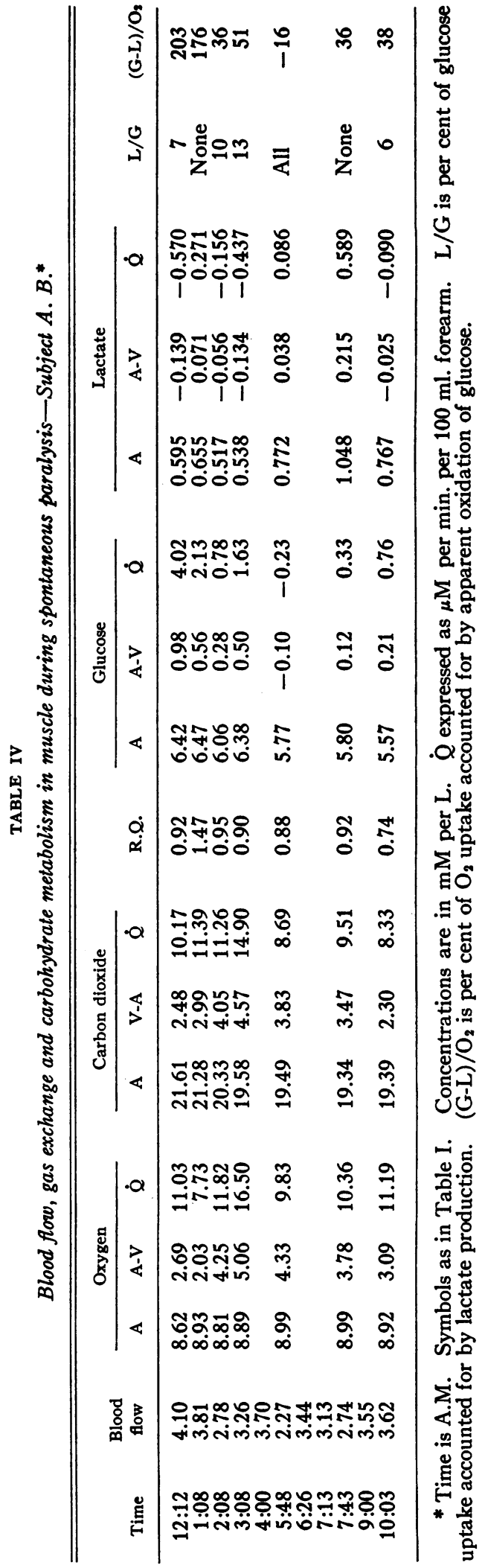




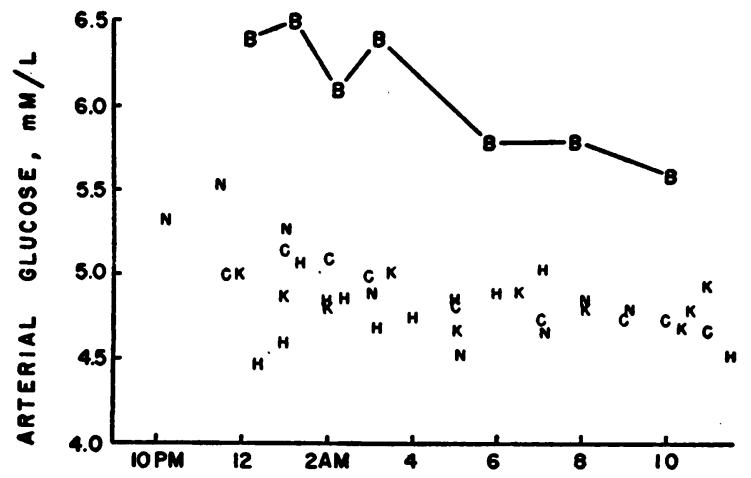

Fig. 4. Arterial Blood Glucose

$B$, subject $A$. B. during attack and recovery; $C, K$ and $N$, normal subjects; $H$, subject $M$. $H$. who failed to develop hypokalemia or clinical paralysis.

potassium movement, or whether they are consequences of the disease. None of these metabolic differences appeared in subject M. H., Study III, during the night in which he failed to have a spontaneous attack.

Concentration of glucose in arterial blood was definitely higher in subject A. B. than in normals during the night (Figure 4), and at least during the first four measurements $A-V$ glucose differences were higher than normal. It has been noted previously (10) that $A-V$ glucose differences varied directly with arterial glucose concentrations in normal subjects during the night. This relation was true also for subject $A$. B., so that the abnormally high glucose $\mathrm{A}-\mathrm{V}$ differences and glucose uptakes in this subject may have resulted from abnormally high delivery of glucose to muscle. Since the concentration of arterial glucose tended to decrease during the night, it is not unexpected that glucose uptake tended to decrease similarly.

Although interpretation of these high concentrations of glucose in arterial blood is complicated by the fact that $\mathrm{A}$. B. had a high carbohydrate diet six and nine hours before the first blood sample was collected, even the last arterial specimen drawn 16 hours after the last meal showed higher than normal glucose concentration, $5.57 \mathrm{mM}$ per L. (mean arterial glucose concentration after 16 to 18-hour fast in 24 normal subjects is $5.01 \mathrm{mM}$ per L. \pm 0.27 S.D.).

Since uptake of glucose by skeletal muscle was at least normal, the high concentration of glucose in arterial blood implies that some other organ failed to remove circulating glucose or that hepatic contribution of glucose was accelerated.

Concentration of lactate in arterial blood was within normal limits during the early part of the study and rose during the later hours (Figure 5), approximately coincident with recovery from paralysis. Lactate production by muscle was erratic. There is no evidence that the rise in arterial lactate concentration was owing to increased production of lactate by skeletal muscle in the forearm. It is possible, however, that other muscles did contribute, since muscle power and deep tendon reflexes were examined from time to time during this period.

During the night and the following morning, forearm blood flow in subject A. B. was within the limits defined by studies of two normal subjects during the night (10) and a larger group of normal subjects during the late morning (9). Nor were there any deviations from normal in $\mathrm{O}_{2}$ uptake, in $\mathrm{CO}_{2}$ production or in $\mathrm{A}-\mathrm{V}$ differences of $\mathrm{CO}_{2}$ or $\mathrm{O}_{2}$ content. However, the arterial concentration of $\mathrm{CO}_{2}$, initially normal, fell to levels lower than those in normal subjects (mean of 24 normal subjects, $21.9 \mathrm{mEq}$. per L. \pm 0.98 S.D.) (Figure 6). Although $\mathrm{pH}$ was not measured, this decrease in arterial $\mathrm{CO}_{2}$ presumably represented extracellular metabolic acidosis.

Mean respiratory quotients of forearm muscles in three normal subjects between the hours of 10 P.M. and 4 A.M. were $0.75,0.84$ and 0.84 . In subject $M$. $H$., during the same time interval

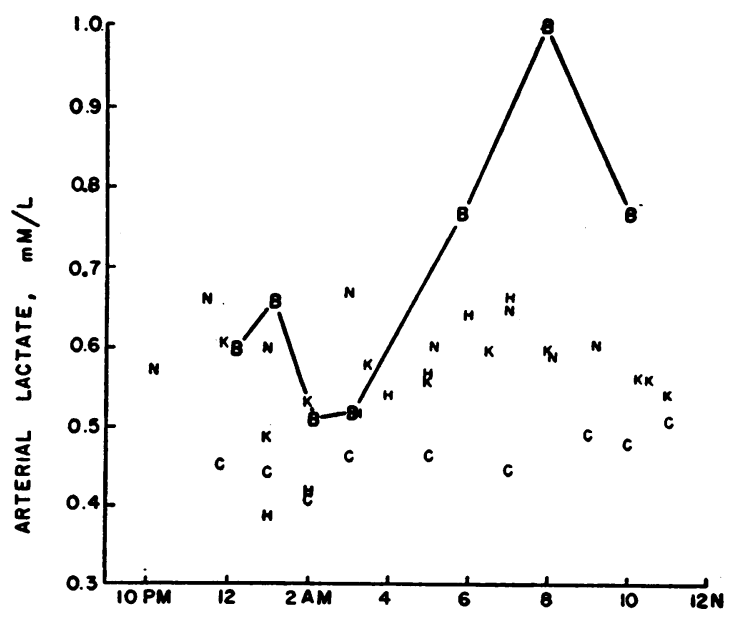

Fig. 5. Arterial Blood Lactate

Symbols as in Figure 4. 


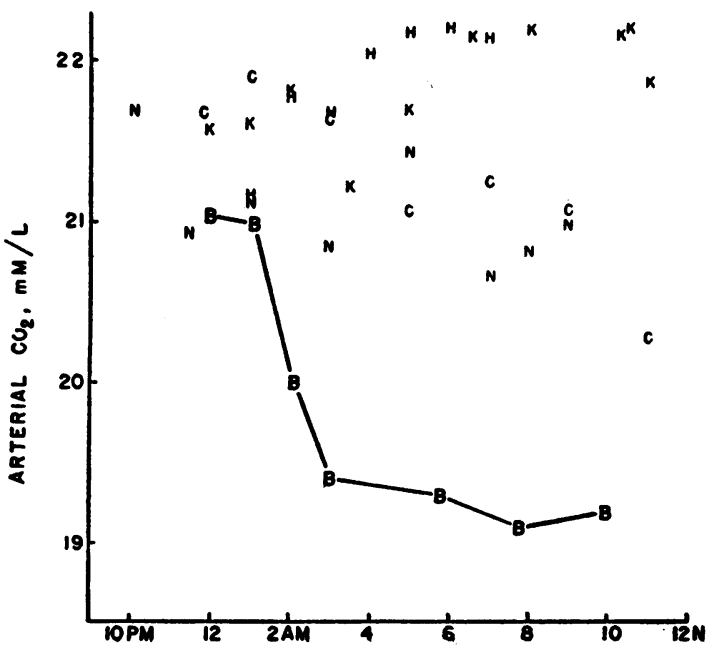

Fig. 6. Arterial Blood $\mathrm{CO}_{2}$ Content

Symbols as in Figure 4.

when he failed to have an attack, the R.Q. was 0.82. In subject A. B. during the spontaneous attack, R.Q. was 1.00 .

The fraction of $\mathrm{O}_{2}$ uptake by muscle which is spent in oxidation of glucose is defined by the following relation (9): 6 (glucose A-V difference minus $1 / 2$ lactate $\mathrm{A}-\mathrm{V}$ difference)/oxygen $\mathrm{A}-\mathrm{V}$ difference. In contrast to data found in normal subjects during the same hours, during the early hours of the attack glucose uptake was greatly in excess of the amount needed to account for all the $\mathrm{O}_{2}$ uptake. Later, glucose uptake decreased and was sufficient to account for only a minor fraction of $\mathrm{O}_{2}$ uptake, as was true in normals. In normal subjects the fraction of $\mathrm{O}_{2}$ uptake accounted for by glucose oxidation varied directly with arterial glucose concentration (10). This was true also in subject A. B.

These data do not explain the exaggerated movement of potassium between plasma and muscle seen during paralysis and recovery. Although unusually rapid uptake of potassium by muscle was associated with unusually rapid glucose uptake, the direction of potassium movement reversed, and potassium moved from muscle to plasma during recovery at a time when arterial glucose concentration was still excessive and glucose uptake by muscle was still relatively large.

Net efflux of potassium from cells under the influence of acidosis has been described (11) and a suggestive correlation between potassium movement from muscle and $\mathrm{CO}_{2}$ production by muscle was found in normal subjects during the night (10). This correlation could be demonstrated for subject $M$. H., who had no attack, but could not be demonstrated for subject A. B. during and following the attack.

The possibility has been considered that changes in concentration of potassium in plasma may be owing to water shifts either from extravascular space or from erythrocytes into plasma. To test this possibility, hematocrits were determined on paired samples of arterial and venous blood throughout the night. Among seven pairs of hematocrits, mean arterial hematocrit was 44.20 , range 43.1 to 45.5 , mean venous hematocrit was 44.26 , range 43.4 to 45.5 , and mean difference between pairs of arterial and venous blood was -0.06 , range -0.5 to +1.0 . Thus there was no evidence of net water shift into plasma.

\section{SUMMARY}

1. A large net uptake of potassium from arterial plasma by skeletal muscle (the forearm) has been demonstrated a) during the development of a spontaneous nocturnal attack of periodic paralysis and b) during the development of a nocturnal attack induced by the administration of glucose and insulin.

2. Movement of potassium out of skeletal muscle has been demonstrated a) during the spontaneous recovery from a nocturnal attack which developed spontaneously and b) during recovery from an attack after oral $\mathrm{KCl}$ administration.

3. The characteristic onset of attacks during the night with spontaneous cure later in the morning seen in many of these patients may be due to exaggerations of the normal diurnal variation in net potassium movement between muscle and plasma.

\section{ACKNOWLEDGMENTS}

We are indebted to the patients for their cooperation, to Dr. David Grob for the opportunity of studying both patients, and to Dr. Saul Farber who had previously studied patient A. B. and sent him to Baltimore for electromyographic studies by Drs. Grob, Ake Liljestrand and Richard J. Johns. Studies of A. B. by Drs. Farber and Hugh J. Carroll were reported in abstract in the J. Clin. Invest., 1956, 35, 702, simultaneously with reports by Grob, Johns, and Liljestrand, J. Clin. Invest., 1956, 35, 708, and our own report, J. Clin. Invest., 1956, 35, 747. Farber and Carroll reported that during an attack of paralysis in A. B. the concentration of potassium in 
plasma from antecubital venous blood was less than the concentration of potassium in arterial plasma. Their observations were made prior to our own studies of A. B. and were unfortunately unknown to us at the time we performed them. We are indebted also to Miss Ellen Rogus and Mrs. Gerda von Ahlefeldt for their assistance.

\section{REFERENCES}

1. Biemond, A., and Daniels, A. P., Familial periodic paralysis and its transition into spinal muscular atrophy. Brain, 1934, 57, 91.

2. Aitken, R. S., Allott, E. N., Castleden, L. I. M., and Walker, M., Observations on a case of familial periodic paralysis. Clin. Sc., 1937, 3, 47.

3. Allott, E. N., and McArdle, B., Further observations on familial periodic paralysis. Clin. Sc., 1938, 3, 229.

4. Pudenz, R. H., McIntosh, J. F., and McEachern, D., The role of potassium in familial periodic paralysis. J. A. M. A., 1938, 111, 2253.

5. Ferrebee, J. W., Atchley, D. W., and Loeb, R. F., A study of the electrolyte physiology in a case of familial periodic paralysis. J. Clin. Invest., 1938, 17, 504 .
6. Danowski, T. S., Elkinton, J. R., Burrows, B. A., and Winkler, A. W., Exchanges of sodium and potassium in familial periodic paralysis. J. Clin. Invest., 1948, 27, 65.

7. Andres, R., Cader, G., Goldman, P., and Zierler, K. L., Net potassium movement between resting muscle and plasma in man in the basal state and during the night. J. Clin. Invest., 1957, 36, 723.

8. Talbott, J. H., Periodic paralysis; a clinical syndrome. Medicine, 1941, 20, 85.

9. Andres, R., Cader, G., and Zierler, K. L., The quantitatively minor role of carbohydrate in oxidative metabolism by skeletal muscle in intact man in the basal state. Measurements of oxygen and glucose uptake and carbon dioxide and lactate production in the forearm. J. Clin. Invest., 1956, 35, 671.

10. Zierler, K. L., and Andres, R., Carbohydrate metabolism in intact skeletal muscle in man during the night. J. Clin. Invest., 1956, 35, 991.

11. Scribner, B. H., Fremont-Smith, K., and Burnell, J. M., The effect of acute respiratory acidosis on the internal equilibrium of potassium. J. Clin. Invest., 1955, 34, 1276. 